\title{
England pays tribute to Philippe Besnard
}

William S.F. Pickering

\section{OpenEdition}

\section{Journals}

Electronic version

URL: http://journals.openedition.org/ress/428

DOI: $10.4000 /$ ress.428

ISSN: $1663-4446$

\section{Publisher}

Librairie Droz

\section{Printed version}

Date of publication: 1 March 2004

Number of pages: $289-291$

ISBN: 2-600-00941-8

ISSN: 0048-8046

Electronic reference

William S.F. Pickering, «England pays tribute to Philippe Besnard », Revue européenne des sciences sociales [Online], XLII-129 | 2004, Online since 06 November 2009, connection on 02 May 2019. URL http://journals.openedition.org/ress/428 ; DOI : 10.4000/ress.428 
William S.F. PICKERING

\section{ENGLAND PAYS TRIBUTE TO PHILIPPE BESNARD}

My contribution to this admirable collection in memory of Philippe Besnard can only be in appreciation of the support he has given to scholars in Durkheimian studies in Britain and his considerable help to me personally. It has been good for today's Durkheimian world as a whole that in his early years he chose an academic career rather than that of a professional double-bass player!

I began serious studies on Durkheim in 1972 and in the isolated Newcastle upon Tyne where I worked. The publication of Steven Lukes's Emile Durkheim in 1973 came as a complete surprise. I had started to prepare Durkheim on Religion and it was around this time that I came into contact with Philippe Besnard. How, precisely, the contact was established escapes my memory but it was doubtless the result of a visit to Paris.

The past 30 years have witnessed considerable changes in studies on Durkheim, which have in the main meant the gradual increase in interested academics, certainly in Britain and indeed elsewhere. Beginning in the 1980s such British scholars as Willie Watts Milller, Mike Gane, Ken Thompson, Mike Hawkins, Josep Llobera, Sue Stedman Jones and others, have all produced work on Durkheim and become associated with the Durkheim Centre in Oxford. Anthropologists such as Nick Allen and Wendy James have also been drawn into these studies which, of course, have extended well beyond Emile Durkheim to include his many disciples, especially Marcel Mauss.

Besnard's most significant contribution to the English- speaking world was in the publication of The Sociological Domain which appeared in 1983. It was based on a special issue of the Revue française de sociologie of 1979 , and this in turn was in part based on papers given at a conference in Paris organized by Besnard in 1976. To this day the book remains an authoritative volume on Durkheim's disciples and is the only one of its kind available in English.

Of very great help and much encouragement to scholars working in Britain and the United States, and indeed elsewhere, was the Etudes durkheimiennes. Bulletin d'information. It came from the hands of Besnard and was distributed free to scholars around the world. This publication, which was virtually annual, was begun in 1977 and ceased publication in 1987 with issue No. 12. Besnard was the leader of Le Groupe d'études durkheimiennes, which was formed in 1975 in the Maison des Sciences de l'Homme. The Bulletin was the focal point of interest among scholars and was as much anticipated, if one dares to say so, as was the Année sociologique in Durkheim's day. After the group was dissolved in 1987, there was a period of non-activity, until Bob Jones of Urbana, Illinois, published along similar lines, Durkheim Studies. Etudes durkheimiennes, which first 
appeared in 1989. When he gave up in 1994 after the publication of six issues, working on what was a somewhat lonely task, the British Centre for Durkheimian Studies was encouraged to take it over, and in so doing extended its scope. Besnard's firm encouragement that the Centre should embark on the project was one of the chief reasons for us going ahead despite an initial reluctance to proceed along such a path. After eight annual publications, Durkheimian Studies/Etudes durkehimiennes, is now to be published by Berghahn Books of New York and Oxford, with the editorship remaining in the hands of the Centre. Thus a direct line of descent extends from Besnard's initiative to our present journal.

Hard work and academic duties prevented Philippe from coming to Britain frequently and there was little reason why he should, since Durkheim studies in the " 70 s and early " 80 s were thin on the ground and no international conferences involving the work of Durkheim were organized. He was certainly not emotionally drawn to England and Oxford as was Marcel Mauss! His first contact with British scholars was with Steven Lukes who visited Paris to carry out research for his doctoral thesis on Emile Durkheim. However, much later, in 1990, he was invited to give a paper on Durkheim and First Names. It was then published in Debating Durkheim (1990). While he was in Oxford on that occasion an event of some consequence occurred. An informal meeting took place at St Antony's College, which included Professor John Davis, the recently appointed head of the Institute of Social and Cultural Anthropology. The main purpose of the meeting was to discuss the creation of a centre for Durkheimian studies in Oxford. There is scarcely any doubt that Philippe's presence and his firm support for such an initiative, coming as it did from the leading Durkheimian scholar and himself a Frenchman, helped to persuade the meeting that such a centre should come into existence. The British Centre for Durkheimian Studies was launched in 1991 under the auspices of the Institute of Social and Cultural Anthropology. When the Centre organized an international conference on Les Formes élémentaires in 1995, Philippe came again. On this occasion Pierre Mauss, nephew of Marcel Mauss, was also present.

From its beginning the Centre adopted an academic approach to Durkheimian studies which, in the first place, is historical. The policy is to annotate and analyse texts of Durkheim and his disciples against the historical and social situation in which they wrote. Only then can one proceed to evaluate what was written and to suggest its applicability to the modern situation. The call, therefore, is back to Durkheim and his ouvre in its entirety. Thus there has always been the need to obtain as far as possible a complete bibliography of Durkheim's works - a project Lukes initiated and which has been continued in the Centre. Besnard's own work stands very much in this critical historical vein. One only has to recall his paper «De la datation des cours pédagogiques de Durkheim à la recherche du thème de son oeuvre» published in 1993, and concerning the Division of Labour, a similar paper «La diffusion de l'édition française» in the same year. His very sharp mind did not tolerate inaccuracies and we in England have welcomed his criticism of certain articles that have appeared in Durkheimian Studies. He was certainly no admirer of post-modernism!

The last piece that he has written for us was the Introduction to the section on suicide in the 4 volume, Emile Durkheim. Critical Assessments of 2001. He regretted that it was inadequate and short because at the time he became aware of 
his degenerating physical condition and simultaneously he suffered a complete loss of material on his computer.

The Centre has received much encouragement and generous help from Philippe, who in so many respects should by rights have been its leader were it based in France. After all, it was he who was the leader of the first group-venture in the study of Durkheim.

The sadness is that illness, which he mentioned to me in 1999, and which accelerated two and a half years ago, has prevented us in Britain, and others in France and elsewhere, from benefitting from his devoted scholarship and energy in fostering studies of Durkheim and his équipe. Particularly notable were his editorial skills. He was the French scholar par excellence to whom with great respect one referred matters relating to Durkheim and his disciples. His judgments concerning the work of other scholars have at times been sharp but they nearly always turned out to be justified. Through his severity as a scholar, however, shined a warm very shuman sentiment and understanding.

British Centre for Durkheimian Studies

Institute of Social and Cultural Anthropology, Oxford

william.pickering@anthropology.oxford.ac.uk 